\title{
Current Individual and Retrospective Factors Associated With Lifelong Learning Among 50-64 Year Olds in the Baltic States
}

\author{
Olga Zamalijeva ${ }^{1}$, Antanas Kairys ${ }^{2}$, Madara Mikselsone ${ }^{3}$, Ieva Reine ${ }^{4}$
}

\footnotetext{
Riga Stradins University, Statistics Unit, 16 Dzirciema St., LV-1007, Riga, Latvia, olga.zamalijeva@gmail.com 2 Vilnius University, Institute of Psychology, 3 Universiteto g., LT-01513, Vilnius, Lithuania, antanas.kairys@fsf.vu.lt Riga Stradins University, Statistics Unit, 16 Dzirciema St., LV-1007, Riga, Latvia, antanas.kairys@fsf.vu.lt

3 Riga Stradins University, Statistics Unit, 16 Dzirciema St., LV-1007, Riga, Latvia, madara.mikelsone@rsu.lv

4 Riga Stradins University, Statistics Unit, 16 Dzirciema St., LV-1007, Riga, Latvia, ieva.reine@rsu.lv
}

\begin{abstract}
Annotation. This research is aimed to analyse the role of current and retrospective factors in participation in educational and training courses among 50-64 year-old adults from the Baltic states. A sample of 3448 working age adults was drawn from SHARE wave 7 database. Analysis shows significant cross-country differences with the highest proportion of attendance in Estonia. Participation is related to personality traits, being active in the labour market, education level, and some retrospective factors.
\end{abstract}

Keywords: lifelong learning, older adults, personality traits, retrospective factors, Survey of Health, Ageing and Retirement in Europe (SHARE).

\section{Introduction}

The changes and technological advancements in modern society are very rapid, thus the ability to adapt to said changes becomes a crucial factor in successful involvement in the labour market, social participation, and healthy ageing. One can rarely expect that the knowledge and skills acquired during early adulthood will be relevant and sufficient in 20- or 30-years' time. Therefore, promotion of accessible adult education and lifelong learning possibilities is now more relevant than ever before in history. Lifelong learning is 
acknowledged as an important strategic goal for educational system in EU (The Council of the European Union, 2018) as well as globally (UNESCO, 2015).

Lifelong learning has been shown to have a beneficial impact on individual and socioeconomic levels. Studies indicate that adult learning is related to better mental and physical health outcomes (Hammond, 2004; Narushima, 2008), better financial situation (Heckman et al., 2017), and greater civic engagement (Rüber et al., 2018). Improvement of skills and competences helps career development and can ensure longer participation in the labour market (Midtsundstad \& Nielsen, 2019) and is perceived by adults as an important source of career and personal development (Gedviliene, 2016). Extension of working life and retainment of employment among older adults is especially important for ageing societies, where the changing ratio of working-age and retired individuals not only drains the pool of potential employees, but also strains the social security and healthcare systems dependent on the financial input of the working population.

Some countries are more successful than others in engaging adults in lifelong learning activities. A recent study shows, that about half of the working age population in the Baltic states don't or have no intention to participate in further education or training (Roosmaa \& Saar, 2017). The same study indicates that education is perceived as less affordable, unavailable, or unreachable, i.e. the respondents encounter institutional barriers, more often than in other European countries. On the other hand, apart from the macrosystem factors, there might be individual or microsystem factors that may be stopping older working-age adults from engaging in available lifelong learning opportunities.

As suggested by the Chain-of-Response model (Cross, 1981), there are three main barriers in adult learning: situational, institutional, and dispositional. Dispositional barriers are related to individual's biases, attitudes toward learning, and self-perception. These perceptions may be linked to individual characteristics, when a person may feel too old and sick, or previous experiences that may result in negative attitudes toward education (Boeren, 2009). Dispositional barriers deserve special attention, according to Roosmaa and Saar (2017), out of all European countries, dispositional, e. i. attitude-related barriers to lifelong learning are most pronounced in the Baltic states. This result calls for in depth investigation of other possible dispositional factors, that go beyond sociodemographic characteristics and may help explain adult engagement in lifelong learning.

In terms of broadening the understanding of dispositional factors, probably the most relatable are personality traits that are referred to as "dimensions of individual differences in tendencies to show consistent patterns of thoughts, feelings, and actions" (McCrae, 2005, p. 194). Big Five personality theory describes Extraverted people to be more friendly and sociable, but also assertive and active; the Conscientious are more goal focused, determined, and organized; higher levels of Agreeableness are associated with being sympathetic and trusting others and the tendency to be cooperative; Neuroticism is indicative of greater anxiousness, emotional lability, and tendency to question own effectiveness; finally, those having higher scores of Openness are more curious about 
the world in general and are more open to new ideas and experiences (Groth-Marnat \& Wright, 2016; Roberts et al., 2007). Personality traits are considered to be stable determinants of various functioning outcomes and a number of behaviours. For instance, Big Five personality traits have been linked to academic performance (Kamarraju et al., 2011) and self-directed learning (Cazan \& Schiopca, 2014) in student samples. Moreover, Brunello and Schlotter (2011) have identified that a number of key competences for lifelong learning may be linked to personality traits. Regardless of limited empirical data in older adult samples, it is safe to assume that personality traits play a significant role in lifelong learning activities.

Moreover, health conditions have considerable associations with lifelong learning. There is a strong and consistent evidence linking educational attainment and better health outcomes (Walsemann et al., 2013), on the other hand, health issues could lower the possibility of attaining education (Haas, 2006). Chae and Kang (2018) suggest that, along with other factors, the health status of older adults is related to active participation in lifelong learning programmes. Additionally, research shows that having multiple chronic conditions affect various areas of individuals' daily life, for instance, those with two or more diseases are more eager to retire (Laires et al., 2019), are less physically active (Vancampfort et al., 2017), are rarely involved in volunteering activities and less likely to drive a car (Galenkamp et al., 2016), which confirms that physical health and chronic health conditions have an immense effect on the individual and might as well become a barrier to seeking education in later life.

Current factors are not the only ones that are of importance in the understanding of adult participation in lifelong learning activities. Life-course perspective emphasises the need to consider personal histories in order to gain greater insight into current individuals' functioning (Elder et al., 2003). What we are today, strongly depends on the entirety of our life history. This notion is also relevant for adult education studies and goes in line with the Psychosocial Interaction model (Darkenwald \& Merriam, 1982), suggesting that childhood environment and early schooling experiences form a specific background for further participation in education. Moreover, it was also assumed that dispositional barriers to adult education may be explained by negative early life schooling experience (Roosmaa \& Saar, 2017). It is also proposed "the learner identity", formed during the initial schooling period, remains relevant during adulthood (Gorard \& Smith, 2007), which supports the need for a life course approach even for the older adult population.

Studies have shown, that early life circumstances are related not only to early development of the child, but also have a significant impact on various aspects of later life. For instance, research results suggest that negative early life experiences are related to the well-being levels among older adults (Bertoni, 2015). However, previous schooling experiences and early life circumstances encompass an infinite number of factors and selecting the ones that might be relevant for lifelong learning is another challenge. The most obvious retrospective factor for older adults is their obtained education level. 
Research shows that those with a higher level of education in early adulthood, are more likely to perceive the value and the usefulness of participation in educational activities in later stages of their life (Lukošiūnienè \& Barkauskaitè, 2013; Roosmaa \& Saar, 2017), and therefore may be more prone to seek further education later on. What is more, selfefficacy beliefs are considered to be linked to adult education (Kurbanoglu, 2003). Academic self-efficacy, defined as a perception of individuals' ability to succeed academically, has a strong relationship to lifelong learning tendencies (Kozikogu \& Onur, 2019). Also, poor health during childhood becomes a barrier to attaining education (Haas, 2006). One of the explanations is that serious illness may result in missing school and falling behind. Finally, not only schooling experiences, but also childhood home environment is believed to be important. The number of books in the child hood home, which is considered indicative of family socioeconomic status and early life skill formation, was also shown to be related to the duration of formal education and lifetime earnings (Brunello et al., 2017). Summing up, these research findings suggest that precursors of lifelong learning in later life may be found in the earlier life stages.

Having in mind that dispositional barriers have been identified as dominating in the Baltic states, it is important to further investigate the factors related to individual characteristics to better understand their role in lifelong learning. Including the personality traits into the analysis can provide additional insight and broaden the understanding of what these dispositional factors are. Moreover, factors related to the development of dispositional barriers, like personal background and childhood learning experiences, cannot be ignored. Thus, the aim of this research is to analyse the role of current individual as well as retrospective factors related to participation in educational and training courses among 50-64-year-old adults from the Baltic states. Subsequently, the objectives of this study were a) to compare the level of participation in educational or training courses across Baltic states; b) to analyse current individual differences (personality traits, health and social-demographic characteristics) of respondents who did and did not participate in educational or training courses; $\mathrm{c}$ ) to analyse differences in retrospective factors (relative childhood mathematical and language skills, schooling experience, educational level and characteristics of childhood home environment) of respondents who did and did not participate in educational or training courses; d) to evaluate the predictive role of current individual and retrospective factors in participation in educational activities.

\section{Research methodology}

\section{Participants}

The data from Survey of Health, Ageing and Retirement in Europe (SHARE) Wave 7 (Börsch-Supan, 2020) was used in this study. The data collection in the Baltic states took place from April to November in 2017. The database provides information on respondents' 
life histories (SHARELife) and includes data on all three Baltic states (Bergmann et al., 2019).

Respondents, who answered the question about their activities in the last twelve months, were included in the analysis. Participants who indicated that they have been diagnosed or currently suffer from Alzheimer's disease, dementia, organic brain syndrome, or any other serious memory impairment $(\mathrm{N}=26)$ were excluded from further analysis. Final sample consists of 3448 respondents aged from 50 to 64 years $(M=57.87$; $\mathrm{SD}=3.92)$ and living in Estonia $(\mathrm{N}=1747)$, Latvia $(\mathrm{N}=752)$ and Lithuania $(\mathrm{N}=949)$. $40.9 \%$ of respondents were male and $71.6 \%$ had a partner living in the household. ISCED 1997 coding was used to identify the level of education at the time of the interview (see Table 1). Almost two thirds of the respondents were employed or self-employed, including working for a family business, and more than $15 \%$ had already retired. Detailed respondent characteristics regarding their education level and employment status can be found in Table 1 .

\section{Table 1}

Sample Education Level and Employment Status

\begin{tabular}{lcclcc}
\hline \multicolumn{1}{c}{ ISCED 1997 } & $\mathbf{N}$ & $\mathbf{\%}$ & Employment status & $\mathbf{~ N}$ & $\%$ \\
\hline $\begin{array}{l}\text { Level 0 (Pre-primary education) } \\
\text { Level 1 (Primary education or first } \\
\text { stage of basic education) }\end{array}$ & 11 & 0.1 & Retired & 532 & 15.4 \\
$\begin{array}{l}\text { Level 2 (Lower secondary or sec- } \\
\text { ond stage of basic education) }\end{array}$ & 282 & 8.2 & $\begin{array}{l}\text { Employed or self- } \\
\text { employed }\end{array}$ & 2215 & 64.2 \\
$\begin{array}{l}\text { Level 3 (Upper secondary educa- } \\
\text { tion) }\end{array}$ & 1408 & 40.8 & $\begin{array}{l}\text { Permanently sick or } \\
\text { disabled }\end{array}$ & 381 & 11.0 \\
$\begin{array}{l}\text { Level 4 (Post-secondary non- } \\
\text { tertiary education) }\end{array}$ & 692 & 20.1 & Homemaker & 87 & 2.5 \\
$\begin{array}{l}\text { Level 5 (First stage of tertiary } \\
\text { education) }\end{array}$ & 1026 & 29.8 & Other & 47 & 1.4 \\
$\begin{array}{l}\text { Level 6 (Second stage of tertiary } \\
\text { education) }\end{array}$ & 23 & 0.7 & & & \\
NA & 2 & 0.1 & & & \\
\hline
\end{tabular}

\section{Measures}

Participation in educational or training course. During the course of the SHARELife interview, participants were asked whether they engaged in a number of social and leisure activities in the past twelve months. One of these activities was listed as "Attended an educational or training course", to which the respondent could respond as "yes" or "no". These data were included in the further analysis as an indicator of participation in lifelong learning activities. 


\section{Current individual factors}

Personality traits. The personality traits of respondents were measured using 10 -item Big Five Inventory (BFI-10; Rammstedt \& John, 2007). BFI-10 consists of short descriptive phrases (e.g., "I see myself as someone who is outgoing, sociable"), that are rated on a five-point scale ranging from 1 - "strongly disagree" to 5 - "agree strongly", and allows to assess respondents' Extraversion, Agreeableness, Conscientiousness, Neuroticism, and Openness. The instrument is used for a brief assessment of five personality traits and has sufficient psychometric characteristics of reliability and validity (Rammstedt \& John, 2007).

Health status. In order to assess the health status, respondents were asked to indicate what long-term conditions they currently had. Respondents were provided with a list of 17 most common long-term conditions in the 50+ age group and were allowed to name other health conditions that they had, that were not mentioned on this list. Based on the data provided, respondents were divided into two groups: 1) having less than 2 conditions; 2) having 2 or more conditions. Additionally, using a single-item Global Activity Limitation Index (GALI; Robine \& Jagger, 2003), respondents estimated how much did their health problems limited the ability to perform everyday life activities. Results were divided into three categories ("severely limited", "limited, but not severely" and "not limited") or two ("limited" and "not limited").

Sociodemographic characteristics. In order to analyse the role of other individual differences, respondent's age and gender were included. Information on whether the spouse or partner lived in the same household was collected. Also, respondents were asked to indicate their current employment status.

\section{Retrospective factors}

Childhood schooling experience and obtained education. Having in mind existing differences in educational systems, as well as numerous educational reforms that took place in the Baltic states over the years, the International Standard Classification of Education (ISCED 1997) was used to code the highest obtained education level of respondents. In order to analyse the role of childhood schooling experience, 3 items were used. Two of these items assess subjective evaluation of the respondents' mathematical and language skills when they were 10 years old, compared to other children in their class. For this evaluation respondents used a 5-point scale, where 1 corresponded to "much better", 5 - "much worse". And one item collected information, whether during their childhood have they ever missed school due to health condition for a month or more.

Childhood family circumstances. Since childhood home environment plays an important role in developing cognitive and learning skills, two items describing this environment were used. The first item was related to the number of books at home at the age of 10. Respondents had to estimate the number of books using five answer options, that included qualitative and quantitative descriptions (1 - "None or very few (0-10 books)"; 2 - "Enough to fill one shelf (11-25 books)"; 3 - "Enough to fill one 
bookcase (26-100 books)"; 4 - "Enough to fill two bookcases (101-200 books)"; 5 "Enough to fill two or more bookcases (more than 200 books)", excluding school books, newspapers, and various magazines. The second item described the family financial situation when growing up, which respondents rated as being "pretty well off financially", "about average", "poor" or "it varied".

\section{Statistical analysis}

The statistical analyses were conducted using IBM SPSS Statistics 26 . The data analyses included $\chi^{2}$ test to compare distributions in different respondent groups, Pearson's correlation coefficient was calculated to evaluate links between the variables. Independent sample Student's t-test was applied to compare means among different groups. Multivariate binary logistic regression was applied to identify predictive variables. The results are considered as significant at a $\mathrm{p}$ value $<0.05$.

\section{Results}

The results show that overall $19.6 \%$ of respondents participated in lifelong learning activities and about every fifth respondent participated in such activities almost every month. Comparison of the distribution across countries included in this analysis shows, that more than a quarter of 50-64-year-olds residing in Estonia attended an educational or training course in the last 12 months (Figure 1).

\section{Figure 1}

Distribution of Participation in Educational and Training Courses Across the Baltic States

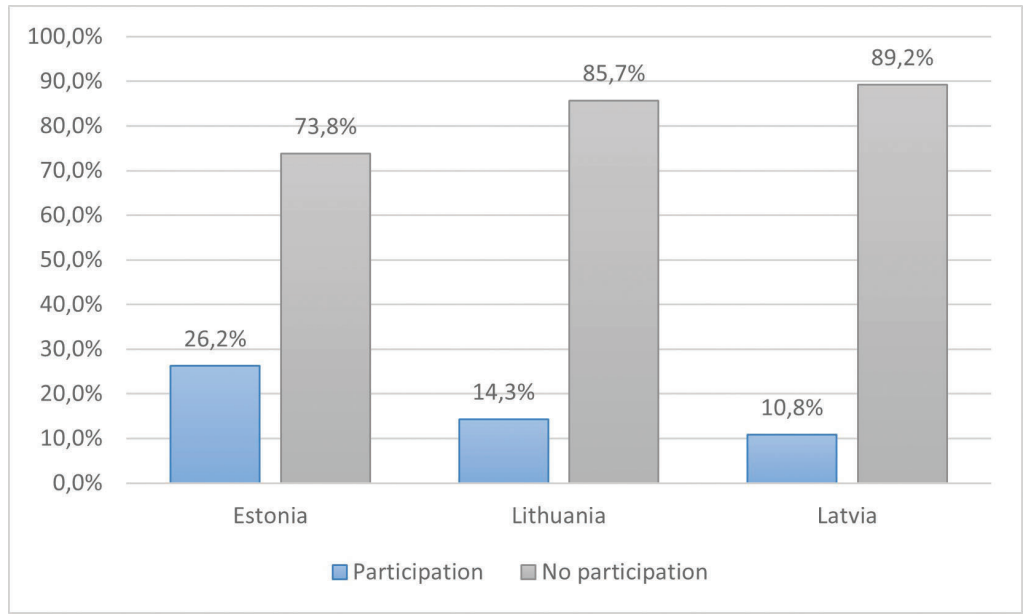


Second, the largest ratio of participation was among Lithuanian respondents (14.3\%) and the lowest number of individuals participating in formal lifelong learning activities was reported in Latvia (10.8\%). Analysis also indicates that the differences in distribution across countries were significant $\left(\chi^{2}=102.54, \mathrm{df}=2, \mathrm{p}<0.001\right)$. This result suggests that there are systemic cross-country differences related to facilitation and promotion of adult education.

In order to evaluate whether personality characteristics may in any way relate to adult participation in lifelong learning, Big Five personality traits were compared between the groups which participated in educational or training course, and those that did not. Results of this analysis show that there are significant differences for four out of five personality measures (Figure 2). The only comparison that showed an insignificant result, was the level of Conscientiousness $(\mathrm{p}>0.05)$. The results indicate that respondents who attended an educational or training course in the last 12 month scored higher on Extraversion ( $\mathrm{t}(\mathrm{df})=7.45$ (3333); $\mathrm{p}<0.001$ ), are more Agreeable ( $\mathrm{t}(\mathrm{df})=4.30$ (3334); $\mathrm{p}<0.001)$ and Open to experience $(\mathrm{t}(\mathrm{df})=11.99(3328) ; \mathrm{p}<0.001)$, but have lower scores in the Neuroticism domain ( $(\mathrm{df})=-7.42(3330) ; \mathrm{p}<0.001)$.

\section{Figure 2}

\section{The Differences in Personality Traits Between Respondent Groups}

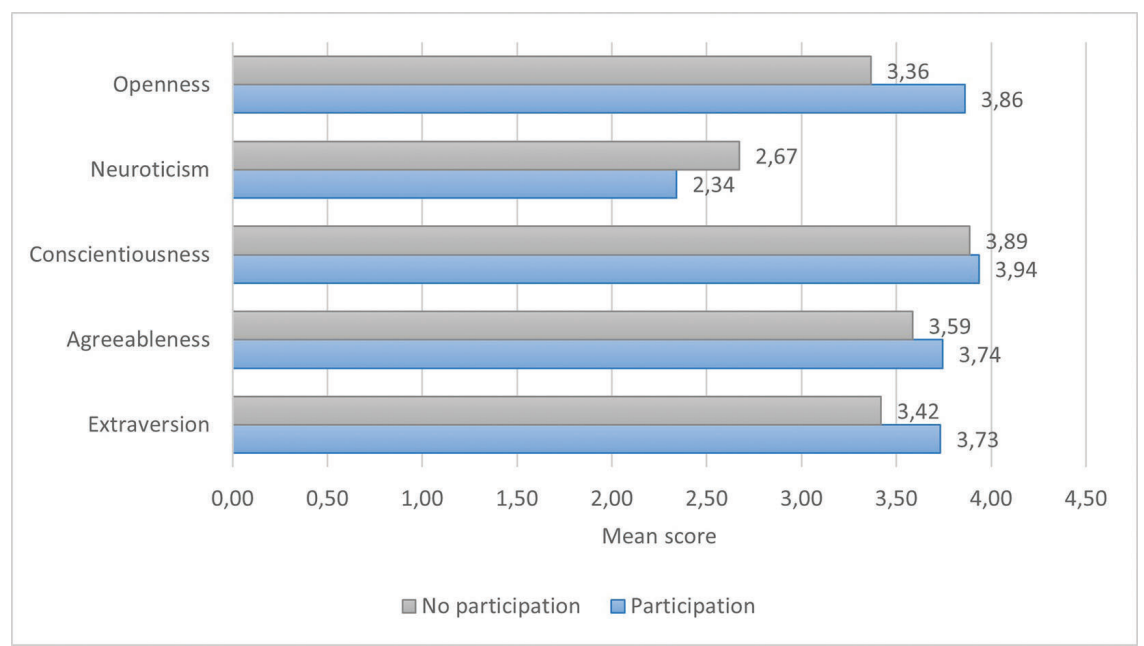

Other individual factors were also included in the analysis. The results show that there were significant age differences $(\mathrm{t}(\mathrm{df})=-3.38(3446) ; \mathrm{p}=0.001)$, i.e. respondents who attended an educational or training course $(\mathrm{M}(\mathrm{SD})=57.41(3.79))$ were younger than the ones that didn't $(M(S D)=57.98(3.95))$, however the mean difference is relatively small. It is also evident that more than three quarters of the respondents involved in educational activities were women, while the "non-participant" group had a more equal gender distribution (Table 2). In contrast to the "learners" of whom the vast majority 
were currently employed or self-employed, $41.4 \%$ of respondents who did not participate in educational or training courses were retired or unemployed. No significant difference in distribution by relationship status was found between the respondent groups.

\section{Table 2}

Distribution by Gender, Relationship and Employment Status Between Respondent Groups

\begin{tabular}{lccccc}
\hline & Participation & No participation & $\chi^{2}$ & df & $\mathbf{p}$ \\
\hline Gender & & & & & \\
$\quad$ Male & $24.0 \%$ & $45.0 \%$ & 98.78 & 1 & $<0.001$ \\
$\quad$ Female & $76.0 \%$ & $55.0 \%$ & & & \\
Has partner in the household & & & & & \\
$\quad$ Yes & $73.5 \%$ & $71.2 \%$ & 1.45 & 1 & 0.228 \\
$\quad$ No & $26.5 \%$ & $28.8 \%$ & & & \\
Employment status & & & & & \\
$\quad$ Retired & $3.0 \%$ & $18.7 \%$ & 265.91 & 2 & $<0.001$ \\
$\quad$ Employed or self-employed & $92.1 \%$ & $58.5 \%$ & & & \\
$\quad$ Not working & $4.9 \%$ & $22.7 \%$ & & & \\
\hline
\end{tabular}

Significant differences were found for both physical health indicators in the distribution among respondents who participated in educational activities and those who did not (Table 3.). Almost twice as many respondents that did not attend any educational or training course within the last year reported severe limitations in their daily life activities due to physical health issues. Results also show that there are fewer people suffering from multiple chronic conditions among the respondents involved in further education.

Table 3

Distribution by Physical Health Outcomes Between Respondent Groups

\begin{tabular}{lccccc}
\hline & Participation & No participation & $\chi^{2}$ & df & p \\
\hline Number of chronic diseases & & & & & \\
Less than 2 & $71.6 \%$ & $60.1 \%$ & 30.45 & 1 & $<0.001$ \\
2 or more & $28.4 \%$ & $39.9 \%$ & & & \\
Limitations due to health & & & & & \\
Severely limited & $8.4 \%$ & $16.7 \%$ & 35.42 & 2 & $<0.001$ \\
Somewhat limited & $27.0 \%$ & $28.9 \%$ & & & \\
Not limited & $64.6 \%$ & $54.4 \%$ & & & \\
\hline
\end{tabular}

Analysis of retrospective factors yielded some significant results as well. Comparison of two respondent groups showed that participants of educational and training courses 
on average assessed their mathematical abilities at the age of ten to be relatively better than the ones of their peers ( $(\mathrm{df})=-10.67(999,62) ; \mathrm{p}<0.001)$. Similarly, respondents involved in educational activities reported to have been better performing in reading and writing, i.e. better language skills ( $(\mathrm{t}(\mathrm{df})=-12.54(986,09) ; \mathrm{p}<0.001)$, compared to their classmates when ten years old.

\section{Figure 3}

The Differences of Relative Childhood Mathematical and Language Skills Between Respondent Groups

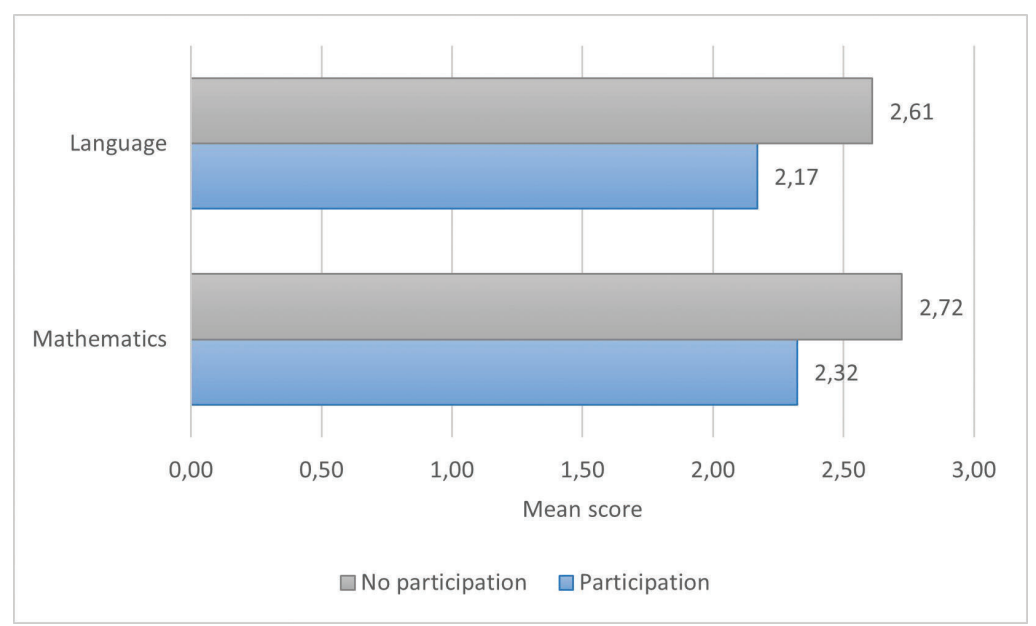

Note. Lower values indicate better assessment of mathematical or language skills.

There were no significant differences among respondent groups related to whether or not they ever missed school due to illness for a month or more. However, the distribution by obtained educational level is unequal among groups. First of all, the number of respondents who obtained none or only a basic degree of education is four times higher among the individuals that have not attended any educational or training course within the last twelve months (2.5\% vs. $10.1 \%$; Table 4 ). Also, the ratio of respondents, who have the first and the second stages of tertiary education among individuals involved in educational activities, is much higher. Regarding the childhood home environment, both indicators revealed significant differences. Respondents who at the age of ten had enough books at home to fill at least one book case make up almost $80 \%$ of educational programme participants, in contrast to $52.3 \%$ in the non-participant group. Even though the difference in the distribution by childhood family financial situation is not as explicit, it is still significant and indicates that respondents who reported their financial situation to be better during childhood, were more likely to attend educational or training course in later life. 
Table 4

Distribution by Schooling Experience, Educational Level and Characteristics of

Childhood Home Environment Between Respondent Groups

\begin{tabular}{|c|c|c|c|c|c|}
\hline & Participation & No participation & $\chi^{2}$ & df & $\mathbf{p}$ \\
\hline \multicolumn{6}{|c|}{ Missed school for 1 month or more } \\
\hline Yes & $11.3 \%$ & $12.1 \%$ & 0.40 & 1 & 0.529 \\
\hline No & $88.7 \%$ & $87.9 \%$ & & & \\
\hline \multicolumn{6}{|l|}{ Obtained education level } \\
\hline Lower secondary or less & $2.5 \%$ & $10.1 \%$ & 326.58 & 2 & $<0.001$ \\
\hline $\begin{array}{l}\text { Secondary and post- } \\
\text { secondary (non-tertiary) }\end{array}$ & $38.7 \%$ & $66.4 \%$ & & & \\
\hline Tertiary & $58.8 \%$ & $23.5 \%$ & & & \\
\hline \multicolumn{6}{|c|}{ Number of books in childhood home } \\
\hline Less than 10 & $6.8 \%$ & $19.1 \%$ & 195.22 & 3 & $<0.001$ \\
\hline About $11-25$ & $15.2 \%$ & $28.6 \%$ & & & \\
\hline About 26-100 & $36.3 \%$ & $32.5 \%$ & & & \\
\hline More than 100 & $41.7 \%$ & $19.8 \%$ & & & \\
\hline \multicolumn{6}{|c|}{ Childhood family financial situation } \\
\hline Pretty well off & $15.3 \%$ & $12.0 \%$ & 14.26 & 3 & 0.003 \\
\hline About average & $67.8 \%$ & $66.0 \%$ & & & \\
\hline Poor & $13.6 \%$ & $19.4 \%$ & & & \\
\hline Varied & $3.4 \%$ & $2.5 \%$ & & & \\
\hline
\end{tabular}

In order to identify the most important predictors of participation in educational and training courses among older adults, multivariate binary logistic regression was used. Since having a partner in the household and missing school for more than one month did not show significant distribution differences, and the number of missing values in assessment of childhood family financial situation exceeded $10 \%$, these variables were excluded from further analysis. Employment status, number of books in the childhood home, and limitations in daily activities due to health were recoded into dichotomous variables.

The results of binary logistic regression analysis show that the model fits the data well, i.e. Hosmer-Lemeshow test yielded a $\chi^{2}(8)$ of 11.11 and was insignificant $(\mathrm{p}=0.196)$. Overall, the model was significant $\left(\chi^{2}(\mathrm{df})=819.02(17), \mathrm{p}<0.001\right.$; Nagelkerke $\left.\mathrm{R}^{2}=0.35\right)$ and correctly classified $82.9 \%$ of all respondent (95.0\% of non-participants and $34.7 \%$ of respondents who participated in education or training course). Results of regression analysis are presented in Table 5. 
Table 5

Results of Binary Logistic Analysis Predicting Participation in Educational or Training Course Over 12 Months

\begin{tabular}{|c|c|c|c|c|c|c|c|}
\hline & $\beta$ & S.E. & $\begin{array}{l}\text { Wald's } \\
\chi^{2}\end{array}$ & df & $\mathbf{p}$ & $\operatorname{Exp}(\beta)$ & $\begin{array}{c}95 \% \mathrm{CI} \\
\text { for } \operatorname{Exp}(\beta)\end{array}$ \\
\hline Constant & -3.07 & 0.97 & 9.93 & 1 & 0.002 & 0.05 & \\
\hline Country (reference category: Latvia) & & & 51.64 & 2 & $<0.001$ & & \\
\hline Country (Estonia vs. Latvia) & 1.00 & 0.16 & 40.49 & 1 & $<0.001$ & 2.73 & {$[2.00-3.72]$} \\
\hline Country (Lithuania vs. Latvia) & 0.27 & 0.17 & 2.34 & 1 & 0.126 & 1.30 & {$[0.93-1.83]$} \\
\hline Age & -0.01 & 0.01 & 0.19 & 1 & 0.660 & 0.99 & {$[0.97-1.02]$} \\
\hline Gender $(0$ - female, 1 - male $)$ & -0.72 & 0.12 & 38.90 & 1 & $<0.001$ & 0.49 & {$[0.39-0.61]$} \\
\hline $\begin{array}{l}\text { Employment status }(0-\text { not working, } \\
1-\text { working) }\end{array}$ & 1.80 & 0.16 & 126.46 & 1 & $<0.001$ & 6.02 & {$[4.40-8.24]$} \\
\hline Extraversion $(1-$ low, 5 - high $)$ & 0.17 & 0.06 & 9.34 & 1 & 0.002 & 1.19 & {$[1.06-1.33]$} \\
\hline Agreeableness (1 - low, 5 - high) & 0.10 & 0.06 & 2.41 & 1 & 0.120 & 1.10 & {$[0.97-1.25]$} \\
\hline Conscientiousness ( 1 - low, 5 - high) & 0.00 & 0.06 & 0.00 & 1 & 0.981 & 1.00 & {$[0.89-1.12]$} \\
\hline Neuroticism (1 - low, 5 - high $)$ & -0.15 & 0.05 & 7.77 & 1 & 0.005 & 0.86 & {$[0.78-0.96]$} \\
\hline Openness (1 - low, 5 - high $)$ & 0.19 & 0.06 & 9.93 & 1 & 0.002 & 1.21 & {$[1.07-1.36]$} \\
\hline $\begin{array}{l}\text { Chronic diseases ( } 0 \text { - less than } 2,1- \\
2 \text { or more) }\end{array}$ & -0.20 & 0.12 & 2.81 & 1 & 0.094 & 0.82 & {$[0.65-1.03]$} \\
\hline $\begin{array}{l}\text { Limitations }(0-\text { not limited, } \\
1 \text { - limited })\end{array}$ & 0.05 & 0.12 & 0.16 & 1 & 0.691 & 1.05 & {$[0.83-1.32]$} \\
\hline $\begin{array}{l}\text { Mathematical skills compared to } \\
\text { others }(1-\text { much better, } 5-\text { much } \\
\text { worse) }\end{array}$ & -0.09 & 0.07 & 1.52 & 1 & 0.217 & 0.92 & {$[0.80-1.05]$} \\
\hline $\begin{array}{l}\text { Language skills compared to others } \\
\text { (1-much better, } 5 \text { - much worse) }\end{array}$ & -0.17 & 0.08 & 4.93 & 1 & 0.026 & 0.84 & {$[0.73-0.98]$} \\
\hline $\begin{array}{l}\text { Level of education (ISCED; refer- } \\
\text { ence category - tertiary education) }\end{array}$ & & & 115.93 & 2 & $<0.001$ & & \\
\hline $\begin{array}{l}\text { ISCED (lower than secondary } \\
\text { vs. tertiary) }\end{array}$ & -1.68 & 0.30 & 31.58 & 1 & $<0.001$ & 0.19 & {$[0.10-0.33]$} \\
\hline $\begin{array}{l}\text { ISCED (secondary and post- } \\
\text { secondary vs tertiary) }\end{array}$ & -1.15 & 0.11 & 106.29 & 1 & $<0.001$ & 0.32 & {$[0.26-0.40]$} \\
\hline $\begin{array}{l}\text { Number of books }(0-\text { less than } 25 \text {; } \\
1 \text { - more than } 25)\end{array}$ & 0.47 & 0.12 & 15.89 & 1 & $<0.001$ & 1.61 & {$[1.27-2.03]$} \\
\hline
\end{tabular}

Analysis of individual predictors shows, that not all variables can significantly explain participation and non-participation. Country of residence can in part explain involvement of working age older adults in lifelong learning, i.e. living in Estonia compared to Latvia was associated with 2.7 times higher likelihood of attending an educational or training course, but Lithuania vs. Latvia was a non-significant predictor. The employment status 
was among the strongest current individual factors, and this result suggests that working adults are up to six times more likely to be involved in further education. Regression results also show that women tend to be more active, however, when analysed together with other factors, age and health-related variables were no longer significant in explaining participation in lifelong learning activities. Moreover, the results also indicate that respondents who have higher scores in Openness and Extraversion, but lower scores in Neuroticism are more likely to be engaged in training. Regarding retrospective factors, the level of obtained education was the most important predictor of participation in educational or training course among older adults, i.e. having lower than secondary education compared to tertiary education was associated with 5.4 times lower chance $(\operatorname{Exp}(\beta)=0.19)$ of participation, furthermore having secondary and post-secondary education compared to tertiary education was associated with 3.1 times lower chance $(\operatorname{Exp}(\beta)=0.32)$ of participation. It is also important to note, that out of two relative childhood skill-related variables, only assessment of language skills remained significant, and the greater number of books in the childhood home predicted a greater likelihood of involvement in further education among older adults.

\section{Discussion}

The results indicated that personality traits can explain participation in further education among 50-64-year-olds living in the Baltic states. First of all, it is important to mention that personality traits are related to a wide range of behaviours, they have been associated with learning styles and academic performance (Cazan \& Schiopca, 2014), and particular traits have been considered to create a favourable foundation for lifelong learning (Brunello \& Schlotter, 2011). This research shows that adult participation in educational or training course can be explained by the level of their Extraversion and Openness, but contrary to what could have been expected, was unrelated to Conscientiousness. For younger adults, Conscientiousness has been found to be the strongest predictor for academic performance (Kamarraju et al., 2011), and is generally related to competence, goal-setting, socioeconomic status, and other favourable outcomes in various aspects of life (Roberts et al., 2007). However, results of this research suggest, that it is unlikely that the engagement of older adults in lifelong learning is practical or is motivated by achievement seeking. Rather, it is due to the possibility of social interaction and satisfaction of the natural intellectual curiosity. In addition, according to the results, higher level of Neuroticism may be considered as a barrier to participation in lifelong learning. Since Neuroticism is associated with higher anxiety levels, pessimism, and stronger reactions to criticism (McCrae, 2005; Roberts et al., 2007), it is possible that older adults, who are prone to negative emotions, also tend to avoid situations where their ability is judged and tested, which is often a part of the training process. Summing up 
the results related to personality traits, it is evident that these findings not only provide additional understanding of the role of dispositional factors in the context of lifelong learning, but may also lay out some initial guidelines for making further education more appealing to older adults. For instance, emphasising the possibility of social interaction during the lifelong learning programmes, as well as skill development, could be viewed as an additional benefit.

Apart from the personality traits, other individual factors also contribute to prediction of adult education. Employment status may be recognised as a factor linked to the situational barriers proposed by the Chain-of-Response Model (Cross, 1981), when lack of time due to busy work schedule could impose additional difficulties in seeking further education (Beoren, 2009). However, many employers nowadays recognise the need to promote qualifications of their employees and may themselves facilitate such activities, thus employer-related situational barriers become less relevant (Roosmaa \& Saar, 2017). Results of this research showed that adults actively involved in the labour market are sixfold more likely to be involved in lifelong learning activities. This result may suggest that working adults feel greater need, or maybe even some pressure from their employer, to acquire or improve work related skills. Furthermore, another situational barrier - family responsibilities (Boeren, 2009) don't seem to play a significant role according to the results of this research, as having a spouse or partner did not show significant differences in participation. In contrast to younger adults, who may be too busy raising and taking care of their children, older adults probably have less time-consuming family responsibilities.

The results regarding the retrospective factors, including schooling experience, childhood home environment, obtained level of education, are consistent with the idea that the foundation for attitudes toward education and subsequent participation in lifelong learning in later life is at least partially formed in childhood and early adulthood years (Gorard \& Smith, 2007; Kozikogu \& Onur, 2019; Roosmaa \& Saar, 2017). An enriched early life environment allows for better development of cognitive and socio-emotional abilities, which in turn may have a positive effect on school performance (Brunello et al., 2017). The number of books at home, which was a significant predictor for participation in adult education in this study, may also be indicative of the attitude towards literacy or education in the family, and these attitudes may be passed on to the child growing up, thus forming predisposition to value and seek constant personal development. In turn, better school performance and skills due to favourable home environment, may result in greater self-efficacy beliefs that are linked to propensity for learning (Kozikogu \& Onur, 2019). Significance of retrospective factors is like a constant reminder, that promotion of lifelong learning should start early, and for the children, who due to socioeconomic family factors grow up in less fortunate environments, the burden of demonstrating the value of education is transferred to school systems and teachers.

Finally, results of this study show that the country of residence can explain engagement in lifelong learning among older adults - Estonia being the front runner, while Latvia and Lithuania are not that different from each other. These results also call for 
further analysis of cross-country differences in systemic promotion of lifelong learning and possible identification of measures allowing to motivate older adults to participate in educational activities, including the ones with lower educational level and not active in the labour market.

This research has its' advantages and limitations. The major advantage is a relatively large sample of older adults, who were enrolled in this study using probability sampling. Moreover, this research includes respondents from all three Baltic states and evaluated current as well as retrospective factors. It also analyses the role of previously understudied individual factor - personality traits - in adult education. The main restrains of this study is the limited information on the type, durations, and regularity of engagement in educational or training courses of study participants, which also limits interpretation of the results in terms of motivation for participation in educational activities. Furthermore, the information available also does not cover informal studies and acquisition of skills and competences without the help or the supervision, i.e. self-education. Thus, it is possible that respondents, who scored higher on neuroticism and lower on extraversion preferred other forms of learning, that do not require working in a group or taking stress-inducing tests. However, this limitation only emphasises the need for further in-depth investigation of the role of personality traits and other psychosocial factors in lifelong learning.

\section{Conclusions}

Results of the current study show significant differences of participation in educational and training courses across Baltic states. The highest ratio of participation was in Estonia (26.2\% in the past twelve months), the lowest - in Latvia (10.8\% in the last twelve months). Country of residence was also a strong predictor of engagement in lifelong learning among 50-64-year-olds, which suggests existing systemic and cultural differences across the Baltic states.

To our knowledge, the role of personality traits has not been previously analysed in the context of lifelong learning among working-age older adults. Based on the empirical analysis of this study it can be concluded that several personality traits can predict participation in educational activities. Adults who have a higher level of Extraversion and Openness, but lower levels of Neuroticism have a greater likelihood to be engaged in lifelong learning. Furthermore, analysis of current individual factors also indicated that employed and female respondents were significantly more likely to be participating in training activities, while age and health-related factors were non-significant for this respondent group.

Regarding retrospective factors, results suggest that previous schooling experience and childhood home environment have a long lasting effect on the subsequent tendency for adult education. The obtained level of education was the most important predictor of 
participation in educational or training course among older adults. Positive assessment of language skills as well as a greater number of books in the childhood home when 10 years old significantly predicted greater likelihood of involvement in further education among the respondents between the ages of 50 and 64 .

\section{Acknowledgment}

The study was performed within the project/agreement No. 1.1.1.2/VIAA/3/19/540 'Challenges of ageing in the Baltic Sea region'.

This paper uses data from SHARE Wave 7 (DOI: 10.6103/SHARE.w7.711), see Börsch-Supan et al. (2013) for methodological details. The SHARE data collection has been funded by the European Commission through FP5 (QLK6-CT-2001-00360), FP6 (SHARE-I3: RII-CT-2006-062193, COMPARE: CIT5-CT-2005-028857, SHARELIFE: CIT4-CT-2006-028812), FP7 (SHARE-PREP: GA N²11909, SHARE-LEAP: GA $\mathrm{N}^{\circ}$ 227822, SHARE M4: GA N²61982, DASISH: GA N²83646) and Horizon 2020 (SHARE-DEV3: GA N676536, SHARE-COHESION: GA N870628, SERISS: GA $\mathrm{N}^{\circ} 654221$, SSHOC: GA N ${ }^{\circ} 823782$ ) and by DG Employment, Social Affairs \& Inclusion. Additional funding from the German Ministry of Education and Research, the Max Planck Society for the Advancement of Science, the U.S. National Institute on Aging (U01_AG09740-13S2, P01_AG005842, P01_AG08291, P30_AG12815, R21_AG025169, Y1-AG-4553-01, IAG_BSR06-11, OGHA_04-064, HHSN271201300071C) and from various national funding sources is gratefully acknowledged (see www.share-project.org).

\section{Reference}

Bergmann, M., Scherpenzeel, A., \& A. Börsch-Supan, A. (Eds.) (2019). SHARE wave 7 methodology: panel innovations and life histories. Munich: Center for the Economics of Aging (MEA).

Bertoni, M. (2015). Hungry today, unhappy tomorrow? Childhood hunger and subjective wellbeing later in life. Journal of Health Economics, 40, 40-53. https://doi.org/10.1016/j. jhealeco.2014.12.006

Boeren, E. (2009). Adult education participation: the Matthew principle. Filosofija. Sociologija, 20(2), 154-161.

Börsch-Supan, A. (2020). Survey of health, ageing and retirement in Europe (SHARE) Wave 7. Release version: 7.1.1. SHARE-ERIC. Data set. https://doi.org/10.6103/SHARE.w7.711

Börsch-Supan, A., Brandt, M., Hunkler, C., Kneip, T., Korbmacher, J., Malter, F., Schaan, B., Stuck, S. \& Zuber, S. (2013). Data resource profile: The survey of health, ageing and retirement in Europe (SHARE). International Journal of Epidemiology, 42(4), 992-1001. https://doi. org/10.1093/ije/dyt088 
Brunello, G. \& Schlotter, M. (2011). Non-cognitive skills and personality traits: Labour market relevance and their development in education \& training systems. IZA Discussion Paper No. 5743, https://ssrn.com/abstract $=1858066$

Brunello, G., Weber, G., \& Weiss, C.T. (2017) Books are forever: Early life conditions, education and lifetime earnings in Europe. The Economic Journal, 127(600), 271-296. https://doi. org/10.1111/ecoj.12307

Cazan, A. M. \& Schiopca, B. A. (2011). Self-directed learning, personality traits and academic achievement. Procedia - Social and Behavioral Sciences, 127, 640-644. https://doi.org/10.1016/j. sbspro.2014.03.327

Chae, S. E. \& Kang, G. (2018). Determinants of older Korean adults' participation in life-long learning programmes and life satisfaction. International Journal of Lifelong Education, 37(6), 689-700. https://doi.org/10.1080/02601370.2018.1528306

Cross, K. P. (1981). Adults as learners. Jossey-Bass.

Darkenwald, G. G., \& Merriam, S. B. (1982). Adult education: Foundations of practice. Harper \& Row. Elder G. H., Johnson M. K., \& Crosnoe, R. (2003) The emergence and development of life course theory. In: J. T. Mortimer, \& M. J. Shanahan (Eds)., Handbook of the life course. handbooks of sociology and social research (pp. 3-19). Springer. https://doi.org/10.1007/978-0-306-48247-2 1

Galenkamp, H., Gagliardi, C., Principi, A., Golinowksa, S., Moreira, A., Schmidt, A. E., Winkelmann, J., Sowa, A., van der Pas, S., \& Deeg, D. J. H. (2016) Predictors of social leisure activities in older Europeans with and without multimorbidity. European Journal of Ageing, 13, 129-143. https://doi.org/10.1007/s10433-016-0375-2

Gedvilienè, G. (2016). The construct of adult learning to learn. Holistinis mokymasis, 2, 13-20.

Groth-Marnat, G. \& Wright, A. J. (2016). Handbook of psychological assessment (6th ed.). Wiley.

Gorard, S., \& Smith, E. (2007). Do barriers get in the way? A review of the determinants on post-16 participation. Research in Post-Compulsory Education, 12, 141-158. https://doi. org/10.1080/13596740701387437

Haas, S. A. (2006). Health selection and the process of social stratification: The effect of childhood health on socioeconomic attainment. Journal of Health and Social Behavior, 47, 339-354. https://doi.org/10.1177/002214650604700403

Hammond, C. (2004). Impacts of lifelong learning upon emotional resilience, psychological and mental health: fieldwork evidence. Oxford Review of Education, 30 (4), 551-568. https://doi. org/10.1080/0305498042000303008

Heckman, J. J., Humphries, J. E., \& Veramendi, G. (2017). The non-market benefits of education and ability. NBER Working Paper Series, No. w23896. https://doi.org/10.3386/w23896

Komarraju, M., Karau, S. J., Schmeck, R. R. \& Avdic, A. (2011). The Big Five personality traits, learning styles, and academic achievement. Personality and Individual Differences, 51(4), 472-477. https://doi.org/10.1016/j.paid.2011.04.019

Kozikoglu, I. \& Onur, Z. (2019). Predictors of lifelong learning: Information literacy and academic self-efficacy. Cypriot Journal of Educational Science, 14(4), 492-506. https://doi.org/10.18844/ cjes.v11i4.3460 
Kurbanoglu, S. (2003). Self-efficacy: a concept closely linked to information literacy and lifelong learning. Journal of Documentation, 59(6), 635-646. https://doi.org/10.1108/00220410310506295

Laires, P. A., Serrano-Alarcón, M., Canhão, H. \& Perelman, J. (2020). Multimorbidity and intention to retire: a cross-sectional study on 14 European countries. International Journal of Public Health, 65, 187-195. https://doi.org/10.1007/s00038-019-01322-0

Lukošiūnienè, V., \& Barkauskaitè, M. (2013). Mokymosi mokytis kompetencija: suaugusiųu požiūris. Pedagogika, 110(2), 41-48. https://doi.org/10.15823/p.2013.1817

McCrae, R. R. (2005). Personality structure. In V. J. Derlega, B. A. Winstead, \& W. H. Jones (Eds.) Personality. contemporary theory and research (pp. 192-214). Wadsworth Publishing.

Midtsundstad, T. \& Nielsen, R. A. (2019). Lifelong learning and the continued participation of older Norwegian adults in employment. European Journal of Education, 54, 48-59. https:// doi.org/10.1111/ejed.12322

Narushima, M. (2008). More than nickels and dimes: the health benefits of a community-based lifelong learning programme for older adults. International Journal of Lifelong Education, 27(6), 673-692. https://doi.org/10.1080/02601370802408332

Rammstedt, B., \& John, O. P. (2007). Measuring personality in one minute or less: A 10-item short version of the Big Five Inventory in English and German. Journal of Research in Personality, 41(1), 203-212. https://doi.org/10.1016/j.jrp.2006.02.001

Roberts, B. W., Kuncel, N.R., Shiner, R., Caspi, A., \& Goldberg, L. R. (2007). The power of personality: The comparative validity of personality traits, Socioeconomic status, and cognitive ability for predicting important life outcomes. Perspectives on Psychological Science, 2 (4), 313-345. https://doi.org/10.1111/j.1745-6916.2007.00047.x

Robine, J. M., \& Jagger, C. (2003). Creating a coherent set of indicators to monitor health across Europe. The European Journal of Public Health, 13(1), 6-14. https://doi.org/10.1093/eurpub/13.suppl 1.6

Roosmaa, E. L. \& Saar, E. (2017). Adults who do not want to participate in learning: a cross-national European analysis of their perceived barriers. International Journal of Lifelong Education, 36(3), 254-277. https://doi.org/10.1080/02601370.2016.1246485

Rüber, I. E., Rees, S. L. \& Schmidt-Hertha, B. (2018). Lifelong learning - lifelong returns? A new theoretical framework for the analysis of civic returns on adult learning. International Review of Education, 64, 543-562. https://doi.org/10.1007/s11159-018-9738-6

The Council of the European Union (2018, May). Council recommendation of on key competences for lifelong learning. https://eur-lex.europa.eu/legal-content/EN/TXT/?uri=uris erv:OJ.C .2018.189.01.0001.01.ENG\&toc=OJ:C:2018:189:TOC

UNESCO (2015). Education 2030: Incheon declaration and framework for action for the implementation of sustainable development goal 4. https://unesdoc.unesco.org/ark:/48223/ pf0000245656

Vancampfort, D., Koyanagi, A., Ward, P. B. et al. (2017). Chronic physical conditions, multimorbidity and physical activity across 46 low- and middle-income countries. International Journal of Behavioral Nutrition and Physical Activity, 14(6), 1-13. https://doi. org/10.1186/s12966-017-0463-5 
Walsemann, K. M., Gee, G. C., \& Ro, A. (2013). Educational attainment in the context of social inequality: New directions for research on education and health. American Behavioral Scientist, 57(8), 1082-1104. https://doi.org/10.1177/0002764213487346

\title{
Individualūs ir retrospektyviniai veiksniai, susiję su Baltijos šalių gyventojų (50-64 m.) dalyvavimu mokymosi visą gyvenimą veikloje
}

\author{
Olga Zamalijeva ${ }^{1}$, Antanas Kairys ${ }^{2}$, Madara Mikelsone ${ }^{3}$, Ieva Reine ${ }^{4}$
}

\begin{abstract}
Rygos Stradinio universitetas, Statistikos skyrius, Dzirciema g. 16, LV-1007, Ryga, Latvija, olga.zamalijeva@gmail.com Vilniaus universitetas, Psichologijos institutas, Universiteto g. 3, LT-01513, Vilnius, Lietuva, antanas.kairys@fsf.vu.lt Ryga Stradinio universitetas, Statistikos skyrius, Dzirciema g. 16, LV-1007, Ryga, Latvija, antanas.kairys@fsf.vu.lt Ryga Stradinio universitetas, Statistikos skyrius, Dzirciema g. 16, LV-1007, Ryga, Latvija, madara.mikelsone@rsu.lv 4 Ryga Stradinio universitetas, Statistikos skyrius, Dzirciema g. 16, LV-1007, Ryga, Latvija, ieva.reine@rsu.lv
\end{abstract}

\section{Santrauka}

Mokymasis visą gyvenimą yra palankus ekonominiu, socialiniu ir individo lygmeniu. Teoriniai šios srities modeliai atkreipia demesị ị edukacinių programų prieinamumą bei individualių veiksnių svarbą. Šio tyrimo tikslas - išanalizuoti 50-64 metų amžiaus Baltijos šalių gyventojų dabartinių individualių ir retrospektyvinių veiksnių sąsajas su dalyvavimu edukaciniuose ir mokymo kursuose.

Tyrime buvo analizuoti 3448 darbingo amžiaus Baltijos šalių gyventojų (40,9 proc. vyrų) duomenys, paimti iš SHARE 7 bangos duomenų bazès (DOI: 10.6103/SHARE.w7.711). Buvo analizuoti duomenys apie dalyvavimą mokymosi veiklose per paskutinius dvylika mènesių, taip pat individualios respondentų charakteristikos (asmenybės bruožai, socialiniai ir demografiniai kintamieji, sveikatos būklè) ir retrospektyviniai veiksniai (vaikystès mokymosi sèkmè, ịgytas išsilavinimas, vaikystès šeimos aplinka).

Rezultatai rodo reikšmingus Baltijos šalių skirtumus: didžiausias procentas respondentų mokymosi veiklose dalyvavo Estijoje, mažiausias - Latvijoje. Analizè atskleidè, kad tie, kurie dalyvavo mokymosi veiklose, turejo aukštesnius atvirumo, ekstraversijos ir žemesnius neurotiškumo bruožų ịverčius. Suaugusieji, kurie buvo aktyvūs darbo rinkoje ir turejjo aukštesnị išsilavinimą, dažniau dalyvavo mokymosi veiklose. Taip pat buvo nustatyta, kad tie, kurių namuose vaikystejje buvo mažiau knygų ir kurie turèjo prastesnius kalbinius įgūdžius vaikystėje, buvo ir mažiau įsitraukę i mokymosi visą gyvenimą veiklas.

Esminiai žodžiai: mokymasis visą gyvenimą, vyresni suaugusieji, asmenybès bruožai, retrospektyvūs veiksniai, Europos sveikatos, senejjimo ir išejimo į pensija tyrimas (SHARE). 